\title{
A THROAT-BYPASS STABILITY SYSTEM FOR A YF-12 AIRCRAFT RESEARCH INLET USING SELF-ACTING MECHANICAL VALVES
}

by Gary L. Cole, Miles O. Dustin, and George H. Neiner Lewis Research Center Cieveland, Ohio 44135

TECHNICAL PAPER to be presented at Eleventh Propulsion Conference cosponsored by the American Institute of Aeronautics and Astronautics and the Society of Automotive Engineers Anaheim, California, September 29-October 1, 1975

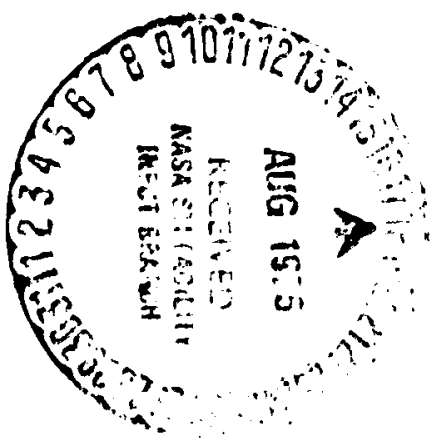


ou atmospheric disturbances are encountered.

This report detalis the final atability oystum hardware and teat procedure. Some wind tunnel icest results are preserited which indicate the stability 11mits that were achieved.

U.S. cuntomary unite were uned in the dealgn of the valves and for recording experimental data. The units were converted to the International Systea of Ualts for presentation in this paper.

\section{ApparatuB}

Inlet

The Inlet used in the wlad tunnel tests wes a odifled TF-12 a1rcraft inlet. It is an axlaymetIlc mired-compression type designed for cruise above Wich 3,0. Th1s inlet was tested at Lew189 prior to belo? modified for the stability oystem.

81g. 1 11lustrated the basic inlet features. A translating spike provides capability for inlet reatart and of $f$ design Mach number operation. Splke boundary layer control is accomplished by a poroun bleed reglon. The bleed alrflow passes overboard through louvered exits at the ends of the opike support struts. Cowl bieed is taken off through the shock trap. The shock trap helps stabllize the terminal shock and provides cooling alr for the engine nozzle. The forward bypass is controlled by the lalet control syslem to match inletengine alrflow requirements. Exress alrflow is diecharged overboard through louvered exits. The aft bypass is manually operated by the pllot to ald the forward bypess in matching-inlet-engine alrLlow. Unless noted otherwise, the aft bypass was closed during these tests. The 1nlet, strached to - bollerplate nacelle contalning a long cold-pige, wae etrut mounted in the wind tunnel. Additionel detalls concerning the inlet systems, instrumentst10n and whd tunnel installation are given in laf. 9. Campbel1's paper 10 also gives additional information regarding the F-12 series alrcraft propulaton syatem.

\section{Throat-Bypasa Stability Sygtem}

Considerable modification of the standard inlet wat required for installation of the throatbypas stablify system. The location of the aysto 18 hown $1 \mathrm{n}$ F1g. 1 with a more detalled schematic of the finel ayatem given In 818. 2. A band of cowl skin juat upstream of the hock trap was replaced with porous skins to allow removal of atablisty bleed alfflow. The entire band had a 40 percent porosity consisting of dietributed noran holes. However, the flnal bleed pattern had a port10n of the bleed urface sealed as shown in 18. 2. The cowling in the bleed region was modiliad further to provide two c1rcumferential rowe of 25 compartmenta. The compartmente housed the alf-acting rellef-type mechanical valves which cortrol bleed plenum exit area and hence stability bleed alrflow. The aft valve compartmente had a cinell anount of continuous bleed tlow, how in 118. 2, to 1mprove 1nlet angle of attack capab111ty and peak recovery characterietica.

Dallke the valves of Ref. 3, the ones used in this ayste do not require a regulated external reference pressure. This 18 accomplished by the orifice in the plston face which allows alr to bleed through into the apring plenum and riterence plenum. Therefore, elmost equal pressures are mainteined on both oldes of the piston. The apring preload alno acte to keep the valves closed. Becauce of th1s aelf-blesing feature, the valves ramain closed for lowly varying disturbances. And 20 w1ll be shown by teet results, the 1nlet control yotem 1s able to handle the slowly varying diaturbances. If a fast disturbance occurs, a differential pressure busldo up ecross the plston, since the orifice flow is upell. When the force on the platon due to the differeatial pressure (about $0.34 \mathrm{~N} / \mathrm{cm}^{2}$ ) exceeds the Initial opring force plus the friction force, the velve will open allowing bleed alrflow through the valve and overboard through louvered exits.

Another feature of these valves is a removable shield and sensing duct (F18. 2). It 1solates the botrom of the piston from the drop ia bleed plenum pressure, $P_{b a}$, that occurs when the valve opens. Th1s drop in pressure would tend to close the unshlelded valve. The benefit of the shleld in this application, particularly for the downatream set of valves, is demonstrated in the Results and Discuesion gection.

F1gs. 3 and 4 are photographs of the injet showing the installation of the throat bypass atability system. Fig. 3 is an Interfor view of the inlet with the splke removed. Some of the porous cowl skin was removed to expose the bleed plenum and valves. Two of the valve piatons were held open to show the stabllity bleed atrflow passage out of the inlet. One valve was removed and replaced by an orffice plate. Sets of different sized orffices were used ingtead of the valves durIng the steady-state tests to determine a $800 d$ bleed hole pattern. Also shown is one of four aymmetrically spaced pipes that supply high pressure ait for a valve lockup system. The lockup system allows the pilot to keep the valves locked in the closed position. The four supply pipes are manifolded and valved so that all stability valves in either row can be locked simultaneously. Fig. 418 an external view of the same region as that hown in F18. 3. Some of the louvered exits, through which the sability bleed af rflow passes overboard, were removed to expose the mounted valvea.

The aft set of valves were used primarily to provide shock stability for alrflow transients (usually internal) which unstart the inlet by moving the terminal hock forward ahead of the throat. The ohield sensing duct was attached to the cowl surface just thead of the hock trap to provide fast reeponee to forward shock motion. Valves in the forward plenums were intended to relleve preseure rlaes in that region due to thinge 11ke angle of attack changes and reduction in Inlet Mach number (upstream or external disturbences). Such pressure risee can cause local choking which will unatert the inlet.

\section{Self-Acting Mechandcal Valves}

A valve 1s ahoun ochematicaliy in greater detall in Fig. 5. It is constructed primarily of titanium and welghs about $1 \mathrm{~kg}$. The platon is gulded on the housing center post with greater clearance between the housing and platon outalde dlameter to prevent interference and binding. Leakage 1o controlled by two graphite placor ringe. The 
valve seat was bellmouth ghaped to give the valve a good flow coefficlent. A strain gage arrangement was used to indicate value piston position. Only elght valves in each row, about $45^{\circ}$ apart, were inotrumented. The orifice between the spring and reference plenums provides damping of plston mot1on. This orifice was sized during the prototype valve tests. 8

F18. 6 is a photograph of a disassembled valve that shows most of the features discussed above. Additional valve detalls are given in Ref. 8.

Some mechanical difficulties were encountered wth the yalves during the rest program. When exercising the valve piston it was found that sometimes the piston would not exceed about 80 percent of its stroke without rotating the piston. Other times it was found that the piston would not close fully, but would remaln open about 20 percent. Th1s is belleved to be due to distortion of the valve housing when the valves are bolted to theit mounting. Reasons for the malfunctions have not been completely determined at the writing of this paper. The problems appear to be minor and are under further Investigation.

\section{Procedure}

The initial wind tunnel testing was devoted to selecting a bleed pattern compatible with the shlelded valve. Various bleed fatterins were obtained by sealing different regions of the stabllity bleed surface. Steady-state inlet and stabillty bleed performance data were obtained for each pattem for various bleed plenum exit areas. "ines were replaced by a fixcd orlftse on the plenum exit as shown in Figs. 3 and 4. To obtain these data, inlet diffuser exit alrflow was varied by a remotely actuated plug assembly mounted at the downstream end of the cold pipe contained in the nacelle. The plug choked the pipe exit airflow. Stablilty 11mits were obtalned for reductions in diffuser exit corrected airflow and changes in ugle of attack.

The ability of the system to absorb transients was then determined. To simulate engine alrflow transients the plug assembly was removed and the alrflow disturbance generator, shown in F1g. 1, was installed. It was mounted at the upstream end of the cold plpe near the compressor face station. Arflow across the assembly was choked. The assembly consisted of five sliding plate valves which were hinged so that they could expand like in umbrella. The amount of assembly expansion and each sliding valve was remutely controlled by electrohydraulic servomechanisms. Diffuser exit a1rflow transients were ubtalned by pulsing the airflow disturbance generator valves $f r o m$ an open to - cloced position. A single trlangular-wave pulse, wich can be transformed by Fourier analysis to obtaln frequency information, was used. Ramp rates varylng from slower than that required to actuate the valves to the maximum rate of the sidding valves were selected. At each rate the pulse amplitude was increased until the inlet unsterted. The maximum decrease in sliding plate valve area that the inlet would tolerate without unstarting was thus obtained. The area change was related to - corrected alrflow change, using steady-state data. The alrflow change was converted to a Stabillty Index (SI) or percent change in atrflow that the Inlet would withstand (see Symbol L1st). These data were obtained for the modifled inlet with and without the valves locked. Tests were also conducted with a forward bypass control system which handled transients that were too low to actuate the valves. These test demonstrate how the two systems complement each other. The forward bypass control shown in F18. I operates in principle 11ke the actual inlet control.9,10 Thts control infers shock position from a single static pressure. The error in shock position is fed to a proportional plus integral controller which commands the forward doors to open or close, depending on whether the shock 18 upstream or downstream of 1 ts desired posit1on.

Inlet tolerance to an upstream disturbance consisting of a transient in tunnel flow-fleld Mach number and flow angularity was also tested. The transient was introduced by rotation of a hinged plate mounted on the tunnel floor at the tunnel geometric throat station. A schematic and photograph of the gust generator device are shown in F1g. 7. The device is simllar to one used previously, il but has provisions to permit remote operation. The plate was inftially neld in a vertical position by a latching mechan1sm. In this position the plate generates a shock wave that is reflected down the tunnel. When the plate $1 \mathrm{~s}$ released, it falls through a $90^{\circ}$ arc, changing the reflected shock position and strength.

\section{Results and Discussion}

\section{Steady-State D1ffuser Ex1t A1rflow Disturbances}

The siahlitty bleed airflow characteristics and inlet performance for the flnal bleed pattern are shown 1n F1g. 8 for a free-stream Mach number of 2.47. The bleed pattern was not optimized to give the best possible performance for internal disturbances as in Ref. 3. Rather, it was selected because it gave adequate results to allow demonstration of both upstream and downstream valve operation under simulated flight conditions. In addition, the inlet with the valves locked closed gave performance about the same as, or bettir than, the standard iniet (no atability bleed) at Mach 2.1 and above.

Date for the stab1l1ty bleed characteristica are shown in F18. 8(a). The plot with bleed plenum pressure recovery $\mathrm{P}_{\mathrm{ba}} / \mathrm{P}_{0}$ shows the maximum potental that can be obtained without the shield on the valve. Maximum potential of the shielded value 18 11lustrated by the plot with sensing duct pressure recovery $P_{s d} / P_{0}$. The valve characteristics cannot be included on these plots because they do not operate for slowly changing disturbances.

Data for each solld curve represents a flxed bleed plenum exit area and were obtalned by varying diffuser exit airflow. The bleed plenum exit areas ranged from 0 to 107 percent of the full open valve geometric area of 53.4 square centimeters. The minimum bleed operation lines correspond to eupercritical operation (terminal shock downstream). Maximum bleed atrflows were obtalned at animum stable or peak recovery conditlone. A maximua tablilty bleed mase-fiow ratin or bout 0.05 was obtalned. The supercritical bleed aas-flow ratio with the valves closed was ondy 0.005 .

The atablitty bleed perforance aps decon- 
acrace the advantage or usiab the onselded type valve. Consider the unshlelded valve firet. When the YF-12 is flying at Mach 2.47 at a typical altitude, an increase of $0.03 \mathrm{in}$ bleed plenum recovery $\mathrm{P}_{\mathrm{b}} / \mathrm{P}_{0}$ would be required to ntart the valve open. Therefore, starting at the operating point ind1caced by the solid symbol, the valvea would not atart open until $P_{b a} / P_{0}$ reaches a value of about 0.37 . Aseuming no additional increase in $P_{b a} / P_{0}$ 19 required to open the valve, the maximum stability bleed mass-flow ratio that could be achleved 1s about 0.04. In actual1ty, some additlonal increase in $P_{b a} / P_{0}$ is required to open the valve. Therefore, the maximim stability bleed mass-flow ratio would be less than 0.04 . Now consider the shielded valve. The same increase in sensing duct pressure recovery 18 required to open the shielded valve. In tisis case, however, the maximum value of $P_{s d} / P_{0}$ increases with increasing mass-flow ratio Instead of decreasing as for $\mathrm{P}_{\mathrm{ba}} / \mathrm{P}_{\mathrm{O}}$. Thus, the ahlelded valve w1ll provide the maximum possible stabllity bleed alrflow. Also, the data for valves closed indlcate that the avaliable change in pressure recovery to open the valve is more than $1 \frac{1}{2}$ times greater for the shlelded valve ( 0.36 to 0.49 for $\mathrm{P}_{8 \mathrm{~d}} / \mathrm{P}_{0}$ versus 0.34 to 0.42 for $\left.\mathrm{P}_{\mathrm{ba}} / \mathrm{P}_{0}\right)$. This could be important at higher altitudes where in increase in recovery greater than 0.03 would be required to open the valve. Also, it might be deasred to operate the inlet at a higher efficiency (h1gher pressure recovery) which would decrease the margin in plenum pressure recovery avallable to open the valve.

The actual stab111ty attained for the Mach 2.47 conditions can be determined from the inlet performance map (F18. 8(b)). The pressure recovery and mass-flow rat 10 terms have been normalized by dividing by their values at the operating point for the thansient tests. Thus the coordinates of the colid symbols are 1.0,1.0. If total temperature is assumed to rematn constant, an alternate equation for atahilicy index. SI, can be obtalned by manipulation of the equation in the Symbol List:

$$
S I=\left\{1-\left[\frac{m_{2} / m_{0}}{\left(m_{2} / m_{0}\right)_{o p}}\right]_{m 1 n s} /\left[\frac{P_{2} / P_{0}}{\left(P_{2} / P_{0}\right)_{o p}}\right]_{m I n s}\right\} \times 100
$$

Thertfore, F1g. 8(b) shows that the maximum SI 18 14.1 for a valve ares of 107 percent. With the valves closed the SI is about 4.5 percent. Thus, the net gain due to the valves opening will be bout 10 percent.

A small part of the stab111ty results from the increase in total pressure recovery as the termital chock moves forward. But most of the stability reulte from the increase in mas8-flow that is bypassed. It should be noted that bleeding ahead of the shock trap resulted in increased shock trap flow, which also contributed to the increase in ctability.

S1m1lar ateady-itate results were obtalned at Wach 2.76 anown by the data in F18.9. In that care the maximum SI was 12.6 percent; and with the valves closed, about 5 percent.

\section{Transient Diffuser ExIt Arflow D1sturbances}

Inlet tolerance to diffuger exlt corracted atrfiow transients is ghown in F/8. 10 for a Mah number or 6.41 . A typicat arsturbance pulse 10 11lustrated in the figure. The resulte are plotted as stabllity index, SI, against a normelized diacurbance rate, NDR. The disturbance rate 19 the absolute ramp rate or time rate of change of the pulse in diffuet exit corrected alrflow. The disturbance rate is converted to NDR by multiplying by 100 over the operating point value of the diffuer exit corrected a1rflow. Thus NDR is the percent change in diffuser exit corrected alrflow per eecond. As NDR Insreases, the atrflow is changing more rapidly and the disturbance has higher frequency content.

Date for Mach 2.47 are shown in P18. 10 for the inlet with the stability valves locked closed, with the valves operating and with the valves and the forward bypass control operating. As expected the inlet has the least tolerance when nelther the values or the forward bypass is operating (circle syobols). However, inlet stab1lity does increase from about 6.5 to 14 percent at the highest NDR, because the inlet volume is able to absorb a larger disturbance as the disturbance rate incresses. When the valves are operating there is no Improvement in inlet stability below a NDR of about 4 because the disturbance rate is too slow to open the values. However, as NDR 1ncreases, the valves open, increasing inlet stablilty by about 7 percent more than with the valves closed. This is olightly less than the 1ncrease predicted by the 3 teadystate data of F18. 8. This discrepancy may be partly due to the larger maximum exit area used during the steady-state tests. The capability of the forward bypass is exceeded at a NDR of about $40 \mathrm{percent} / \mathrm{sec}$. Above 40 only the stab111ty valves provide the increase in inlet stability. Between 4 asi i 0 hise vaives eshance the capability of the forward bypass control system. Below a NDR of 4 the forward bypass system provides large amounts of stab1lity where the disturbance rates are too slow to open the values. If desired the amount of overlap of the two systems could be adjusted by changIng the reaponse of the forward bypass control system or the values. For example, a slower bypass system could be used or the valve response could be changed by varying the reference orifice size.

The stablilty that would be provided by the forward bypess system is accually lese than that shown in F1g. 10. The reason for this is that these tests were conducted with the forward bypase initlally closed to make $1 t$ easter to relate the alrflow disturbance generator area change to a corrected airflow change. In $\$ 1$ ight at Mach 2.47 the forward bypass would be partially open. It would therefore reach lis maxlmum flow area for a smaller disturbance. The corresponding steady-state atablitey that would be provided by the forward bypass control under these conditiong 1 s about 20 percent. Stablitity data were also obtained for the standard inlet (without porous coul bleed) but are not thom in F1g. 10. In general, the standard 1nlet stability was 3 to 4 percent less than the modified inlet with the values locked closed.

Similar translent results were obtalned at Mach 2.76 as shown by the date in F18. 11. The valves appear to begin work $\ln _{B}$ at allghtly lower NDR then at Mach 2.47 . This could be due to a h1gher free-stream total pressure at Mach 2.76 . The valves again provide an additional stabllity of 7 percent - about the same as that indicated by the ateady-state data of F18. 9 . 
The data whth the torward oypasa controd operational indicate that the control is effective to a h1gher NDR than at Mach 2.47. This could be due to the higher gain of the pressure feedback s1gnal to diffuser exit alrflow which results in a higher control loop gain. The actual inlet control adfusta the controller gain to compensate for this, but the control laged in these tests did not. The uteady-state stab1l!ty that would be provided by the forward bypass control under flight condition 18 19 percent. The standard inlet stability was 1 to 2 percent less than the modified inlet with the valves locked.

\section{Angle of Attack and Mach Number Disturbances}

Steady-state data showing the inlet colerance to angle of attack at Mach 2.47 is given $1 \mathrm{n}$ F18. 12. These data were taken with flxed exits. The data Indicate that the inlet would have an angle of atrack capability of about $2^{\circ}$ with the valves locked closed. When the valves are operational, this is more than enough angle of attack capability to 8 ive the necessary increase in bleed plenum pressure rtcovery (about 0.03 ) to open the valves. As can be seen from F1g. 12, relatively mall valve openings allow quite large angle of attack capabilities. It should be remembered that if a change in angle of attack occurs too slowly, the valves w1ll not open. However, those disturbances should be handled by the inlet spike control.

The Inlet tolerance to the disturbance created by the wind tunnel gust generator is shown in F1g8. 13 and 14. For the transient of F1g. 13 the Initial Mach number and flow angle at the spike tip were 2.55 and $0^{\circ}$, respectively. The gust generator created a change of about 0.15 in Mach number and $2.4^{\circ}$ in angle of attack. The change in conditions occurred in about. 0.025 second. The valve trace shows the valve opens about 25 percent and then -tarts to dritt closed. This demonstrates the translent operating nature of the pitives. Only one other upstream valve and no downsi:"can valves were observed to open during the transient. (Recall that only 8 valves in each row are instrumented.) About 1.25 saconds after the disturbance occurs, the 1nlet unstarted as shown by the sharp drop in bleed plenum and cowl surface stat1c pressures. (The cowl pressure is at the same axial location as the forward values.) The noise observed on the valve position trace after unstart, is belleved to be due to excltation of a resonance comewhere in the otrain gage setup, and not to actual piston motion. The Inlet unstarted in 0.3 second for the -ame disturbance when all the valves were locked closed. A 1-centimeter spike translation was required to prevent the inlet from unstarting. The 1.25 seconds should be adequate time for the inlet spike control system to act to prevent unstart, but the 0.3 second would be marginal.

$A$ eecond translent is shown in FIg. 14, in wh1ch the Intilal Mach number and flow angle were 2.68 and $0^{\circ}$. Al instrumented upstreas valves and 2 downstream valves were observed to open for this disturbance. The typlcal upstrean value trace shows the valve opening about 30 percent and then drffting closed. Just prior to unstart the inlet went into an unexplained unstable oscillation visbie in the pressure traces. The lnlet unstarted about 1.68 conds after the disturbance occurred. With all va ves locked closed, the inlet unstarted in legs than 0.1 second. In this case a spike cranslation of 4 centimeters was required to prevent inlet unstart. At the maximum epike travel rate. this travel would require more than $0.3 \mathrm{sec}-$ ond. Thus, without the valves operating, the inlet apike control aystem would be incapable of compeneating for the disturbence.

\section{Surfarary of Resulte}

A throat bypase atab111ty aystem in a YF-12 alrcraft inlet was demonatrated by wind tunnel teating. The system concept should be suttable for fl1ght testing on a NASA YF-12 research alrcraft. Stabilicy bleed atrflow is removed through a porous bleed region just ahead of the inlet shock trap. Tro clrcumferential rowe of rellef-type mechanicel valves control bleed plenum exit ared and, hence, bleed alrflow. The valves have a sield and duct which sense an actuating pressure rather than being actuated directly by the bleed plenum presoure. Such an arrangement provides better valve response to afrflow disturbances in this application. By design, the valves do not open for slowly varying disturbances to eliminate the need for an extermal, regulated reference pressure. A lockup system allows the pllot to lock all valves closed in either row.

The inlet was subjected to single triangular wave pulses in diffuser exit corrected alrflow at Mach numbers of 2.47 and 2.76 . The aft valves permitted additional decreases in airflow of up to 7 percent of the operating point airflow, at rates faster than can be handled by the inlet forward bypass control system. Since the forward bypass control system handles disturbances that are too slow to actuate the valves, the two systems were found to complemint each other quite well.

The Inlet was also subfected to a disturbance consisting of a decrease in Mach number and an increase in angle of attack produced by tunnel gust generator. For this type of disturbance, the forward valves relleve pressure rises that could result in local choking and inlet unstart. It wes found that the valves kept the Inlet started long enough for the inlet spike control system to have prevented unstart. W1 th the valves locked closed, the inlet unstarted rapidly and would not have given sufficient time (or at best, would have been marginal) for the inlet control system to act.

Some minor mechanical difficulties were encountered with the valves. These problems do not appear to be serlous and are under further Invest1gation. 


\section{Symbol Liat}

FIY

forwerd bypase

M Mach aumber

mate flow rate, $\mathrm{kg} / \mathrm{sec}$

ing/s corrected afrflow, $\mathrm{kg} / \mathrm{aec}$

NDR normal1zed diaturbance rate, $\mathrm{NDR}=\mathrm{SI} /(\Delta t / 2)$, percent/sec

P totel preasure, $\mathrm{N} / \mathrm{cm}^{2}$

SI stabildey 1adex,

$$
\text { sI }=\left\{1-\left[\left(\frac{m \sqrt{\theta}}{\delta}\right)_{\text {m1nd }} /\left(\frac{m=\sqrt{\theta}}{\delta}\right)_{\text {op }}\right]_{2}\right] \times 100,
$$

percent

$\Delta t$

trisagular wave pulau width, Bec

a angle of attack, deg

8 ratio of local total pressure to atandard cea level pressure

- ratio of local total temperature to standard sea level temperature

Subecr1pt8:

be bleed plenum-afe compartment (Fig. 2)

if bleed plenum-forward cuapas Lwent (F1g. 2)

flt flight condition

mins minimum stabla (just before unitart) operation

op operating point conditions for transient testo

ad shielded value sensing duct (F18. 2)

o free-atream conditione

2 diffueer exit (compressor face) station

\section{Mererencea}

1. M1tche1l, G. A. and Sandera, B. W., "Alrflow Control Syetem "cr Supersonic Inlets." Pateat No. 3, 799, 475, lin1ted States, Mar. 1974.

2. Hooreheed, J. R., "Development of the Boelng SST Inlet, Control, and Power Syetem," SAE Papar 670318, New York, N. Y., 1967.

3. Sundera, B. W. and Matchell, G. A., "Increating the Stable Operating lange of a Whach 2.5 Inlet." AIM, Paper 70-686, San Dfego, Cal1f., 1970.

4. Senders, B. W. and Mitcha11, G. A., "ThroatBypans Bleed Systems for Increasing the Stable Afrflow lange of a Mach 2.50 Axisymetric Inlet with 40-Percent Internal Contraction," M X-2779, Mag 1973, NASA.

5. Mitche11, G. A. and Sanders, B. W., "PredeureActivated Stability-Bypass-Control Valves to Increase the Stable A1rflow Range of a Mach 2.5 Inlet with 40 Percent Intermel Contract1on," TM X-2972, May 1974, NASA.

6. Blausey, G. C., Coleman, D. M., and Harp, D. S., "Feastbility Study of Inlet Shock Stab1lity System of YF-12," SP-1964, Lockheed A1rcraft Corp., Burbank, Calff. (also NASA CR-134594).

7. Webb, J. A., Jr. and Dustin, M. O., "Analysis of - Stability Valve System for Extend1ng the Dynamic Range of a Supersonic Inlet," TM X-3219, May 1975, NASA.

8. Dustin, Miles O. and Nelner, George H., "Evaluation of Proznrype Rellef Volvoe noot mad far YF-12 Inlet Stability System by Step Responses." IM X-3262, 1975, NASA.

9. "Wlnd-Tunnel Installation of Full-Scale Flight Inlet of YF-12 A1rcraft for Steady-State and Dynam1c Evaluation," IM X-3138, Nov. 1974, NASA.

10. Campbe11, D. H., "F-12 Series A1rcraft Propulsion System Performance and Development," J.Alrcraft, vo1. 11, Nov. 1974, PP. 670-676.

11. Sandera, B. W., B1shop, A. R., and Webb, J. A., Jr., "Gust Generator for a Supersonic W1nd Tunnel," TM X-3120, Dec. 1974, NASA. 


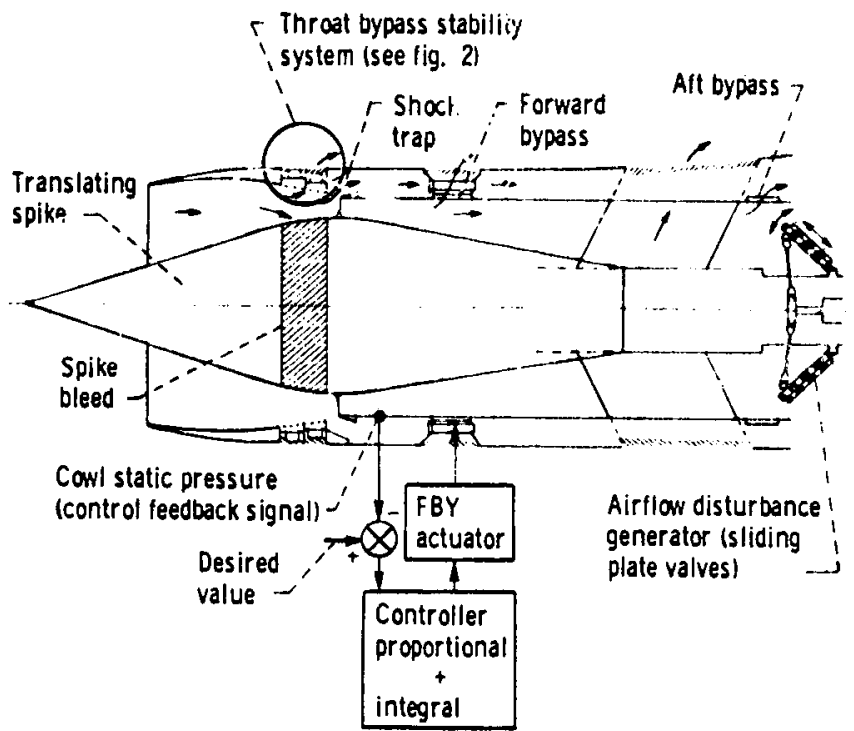

Figure L - Schematic of YF-12 inlet showing bleeds and bypasses and installation of throat-bypass stability system.

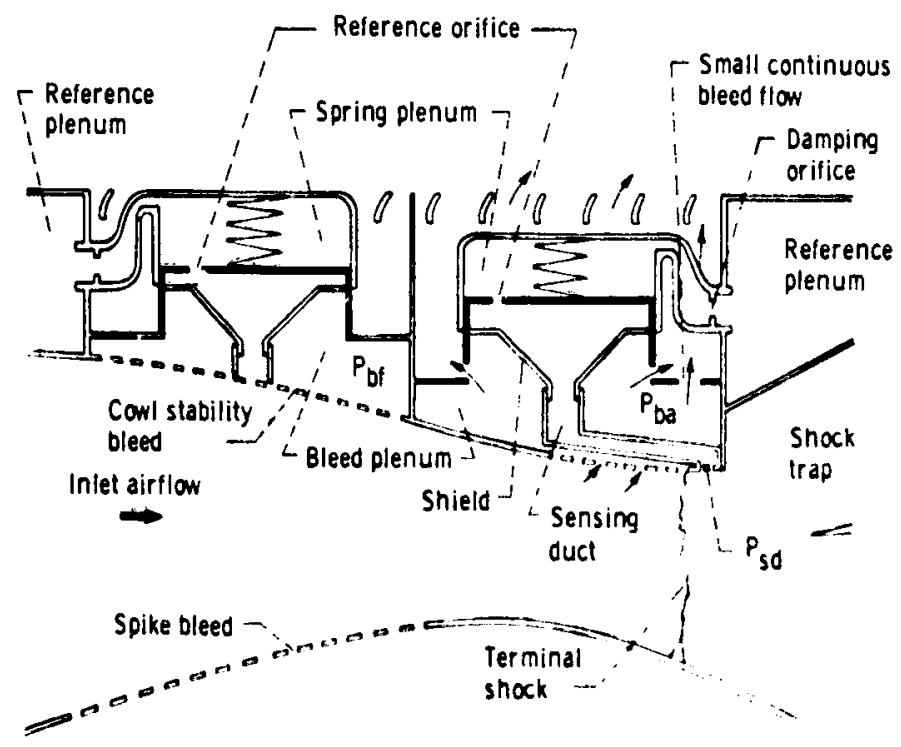

Figure 2 - final throat-bypass stability system instalied in Yf -12 inlet 


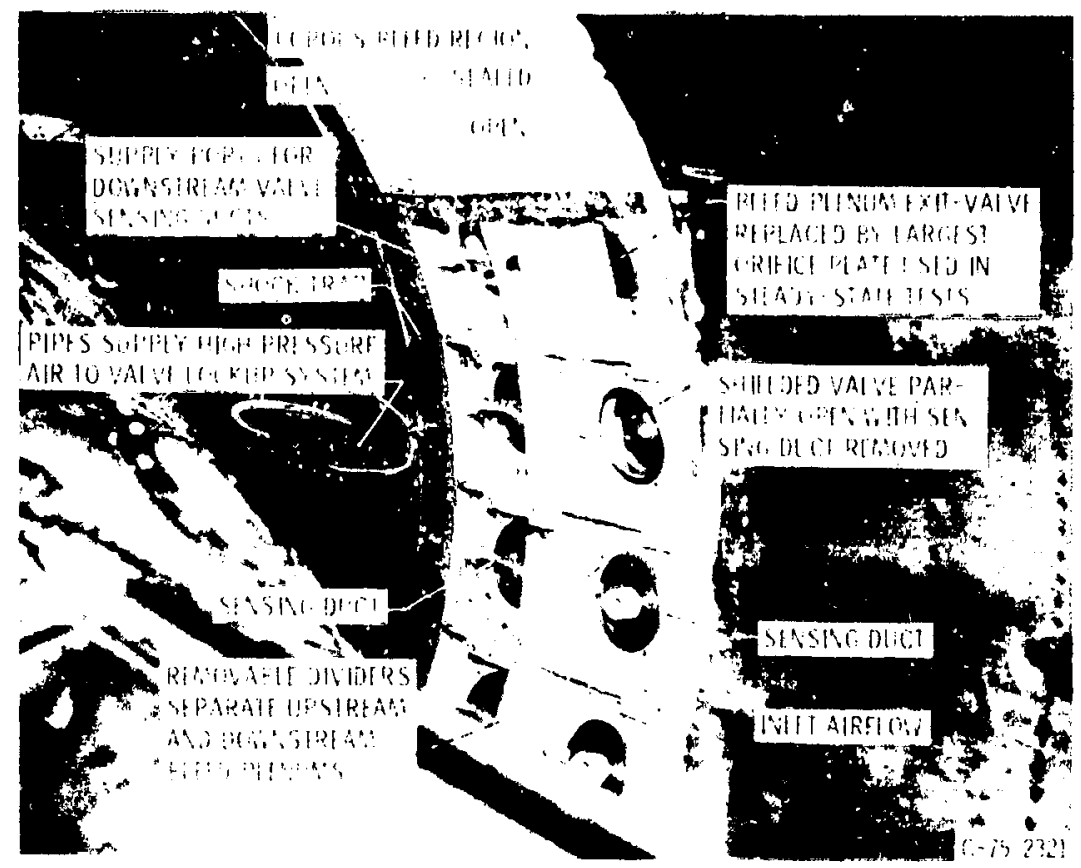

Fiqure 3. - Interrial view of inlet showing porous cowl bleed region and throat bypass stability system installation with spike removed.

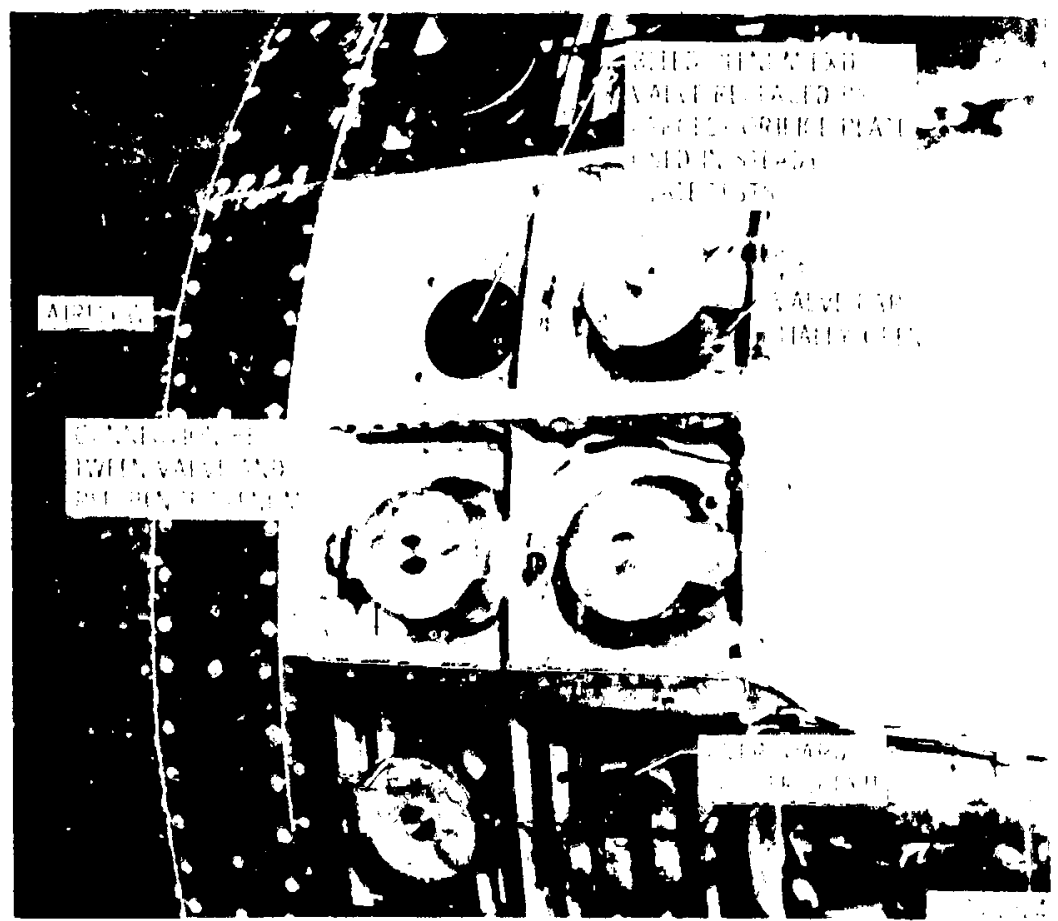

Figure 4. - Extrenal vinu of inlet shov. installation of throat hypass stability systert. 


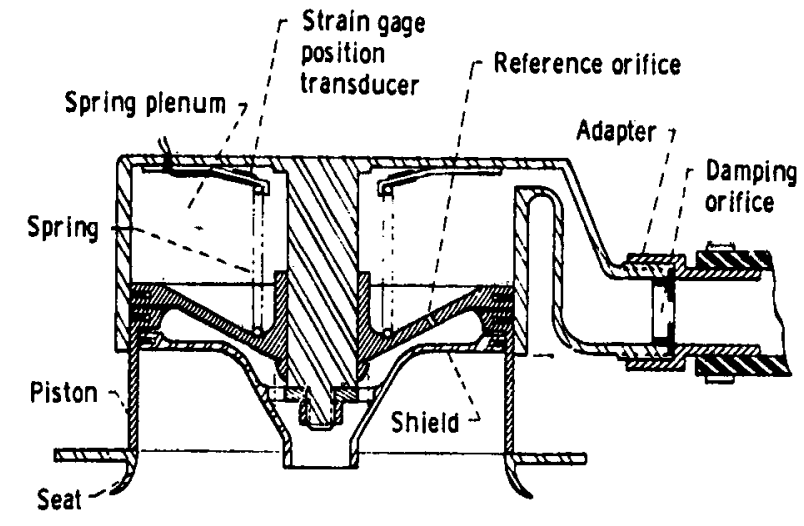

Figure 5. - Details of stability system relief valve.

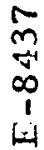

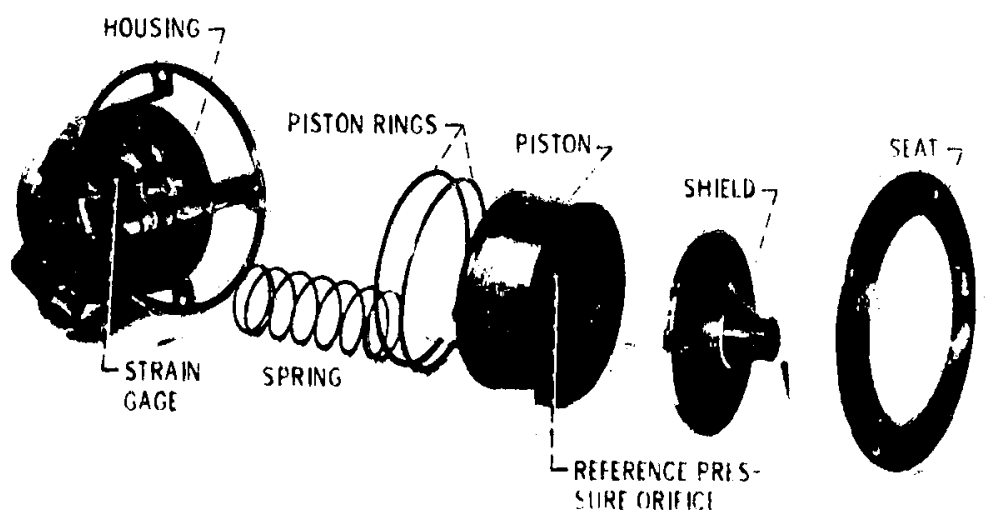

Figure 6. - Disassembled stability system relief valve. ${ }^{C-75-2482}$ 


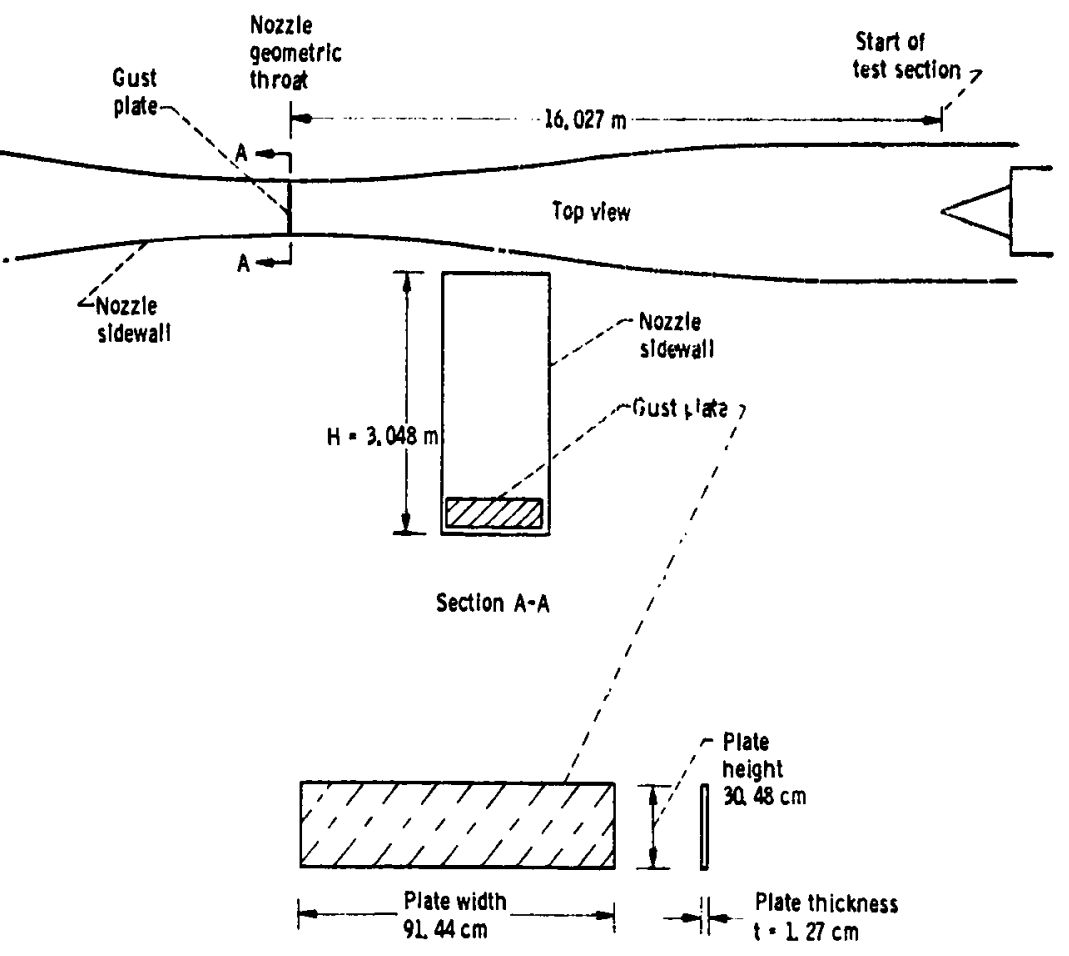

(a) Schematic showing location and size of gust generator.

Figure 7. - Details of gust generator in $10^{\prime} \times 10^{\prime}$ Supersonic Wind Tunnel.

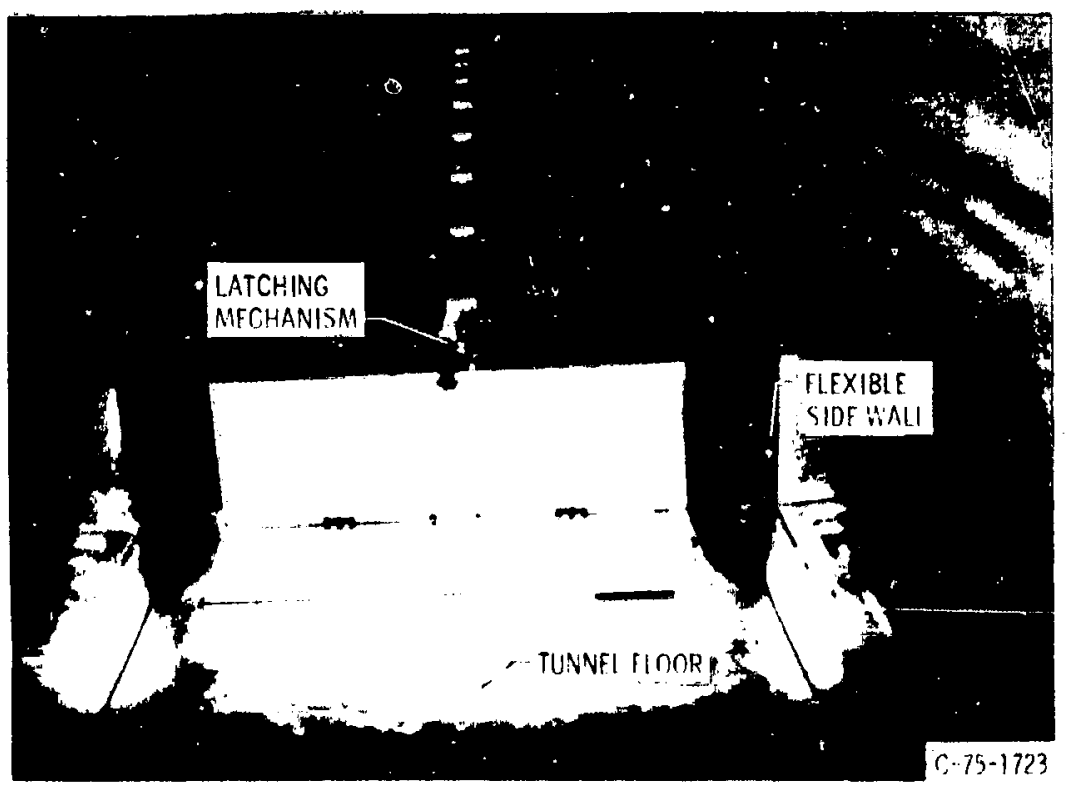

(b) PHOTOGRAPH OF GUST GENERATOR LOOKING UPSTREAM.

Figure 7. - Concluded. 


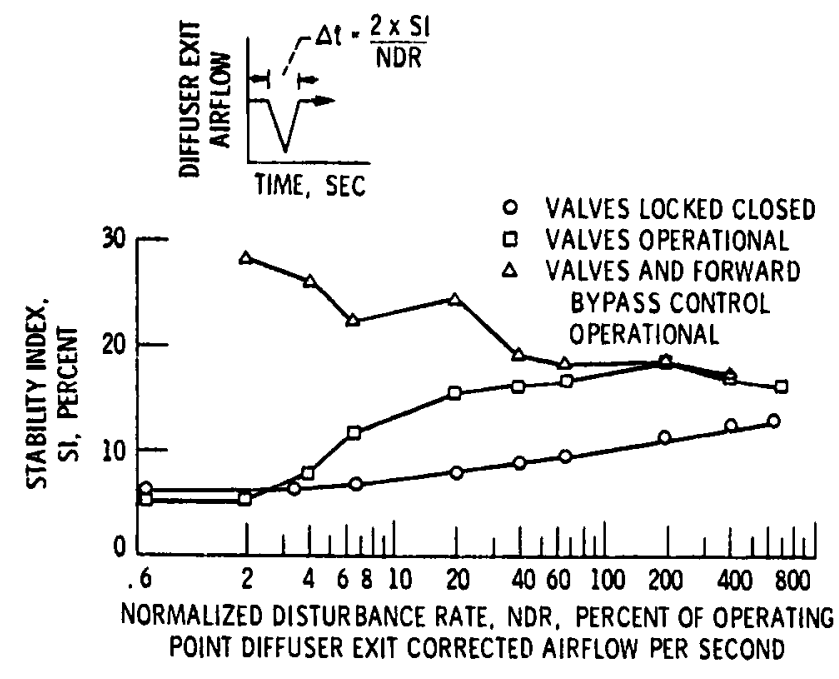

Figure 1Q - Inlet transient stability when subjected to a single triangular pulse in diffuser exit corrected airflow. Inlet at Mach 247 and approximate flight angle of attack conditions. (Corresponding steady-state performance shown in fig. 8.)

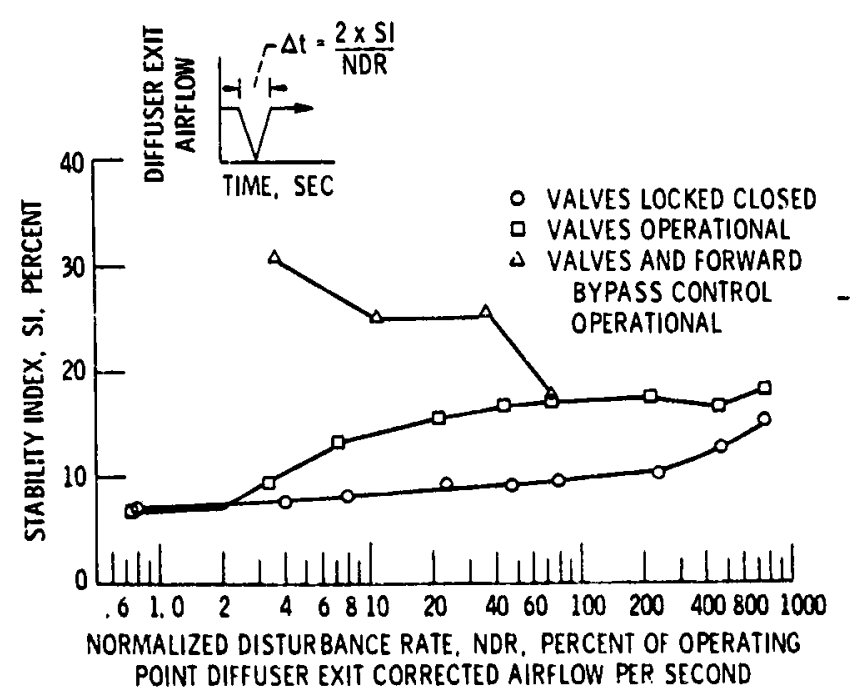

Figure 11. - Inlet transient stability when subjected to a single triangular pulse in diffuser exit corrected airflow. Inlet at Moch 2.76 and approximate flight angle of attack conditions. (Cor responding steady state performance shown in fig. 9.) 


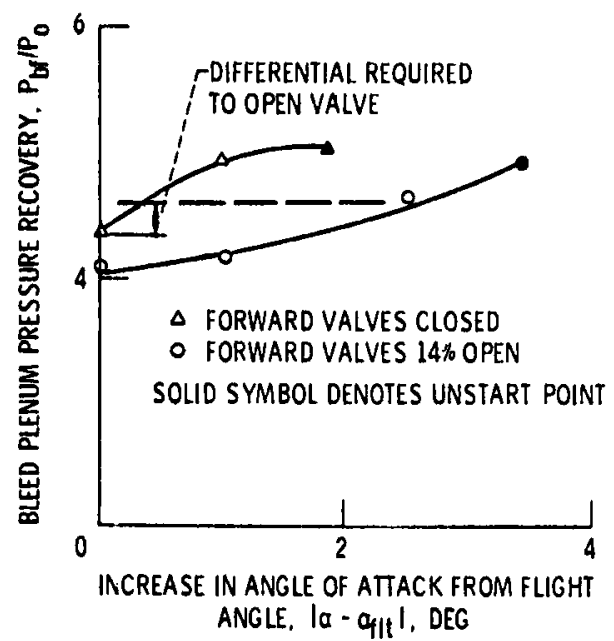

Figure 12 - Typical steady-state data showing bleed system performance for changes in inlet angle of attack Mach number 247 , spike retracted $1.27 \mathrm{~cm}$ from scheduled position, downstream valves closed.
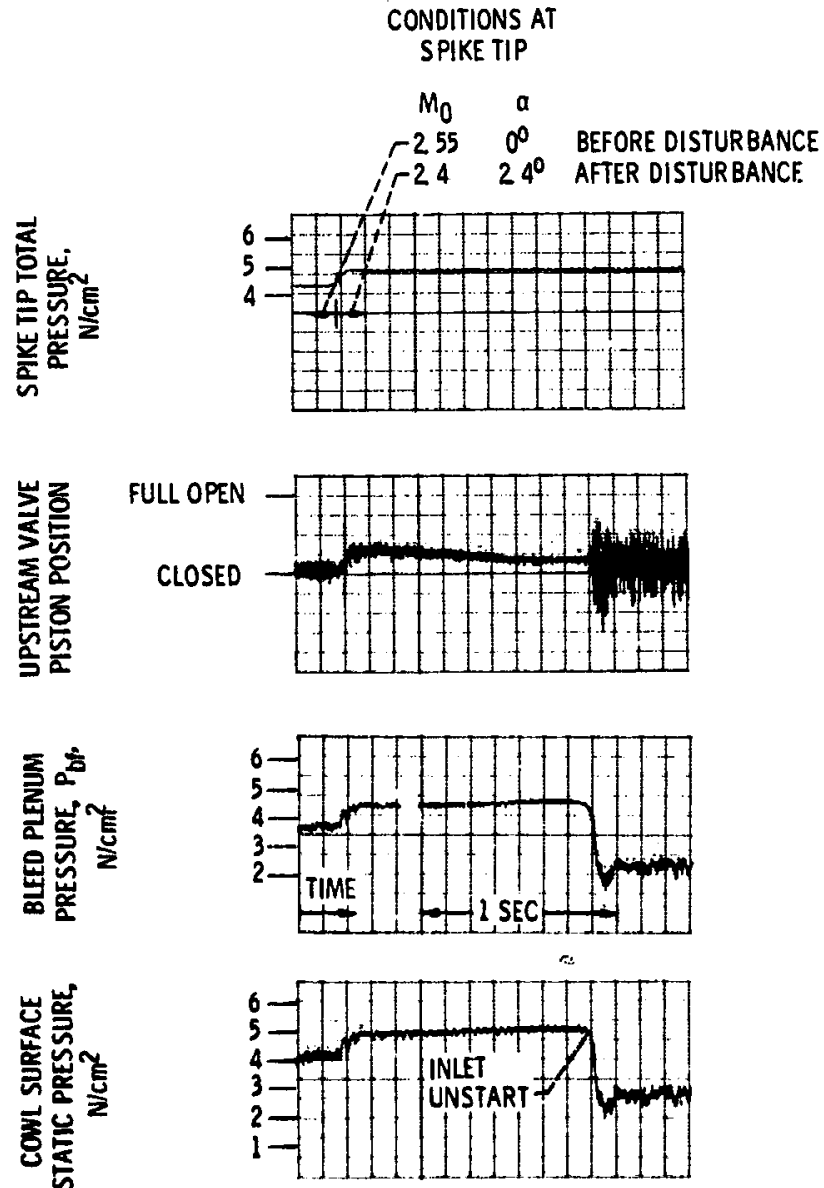

Figure 13 - inlel response to tunnel gust generator disturbance. ivalve located at top of inlet looking downstream. I 


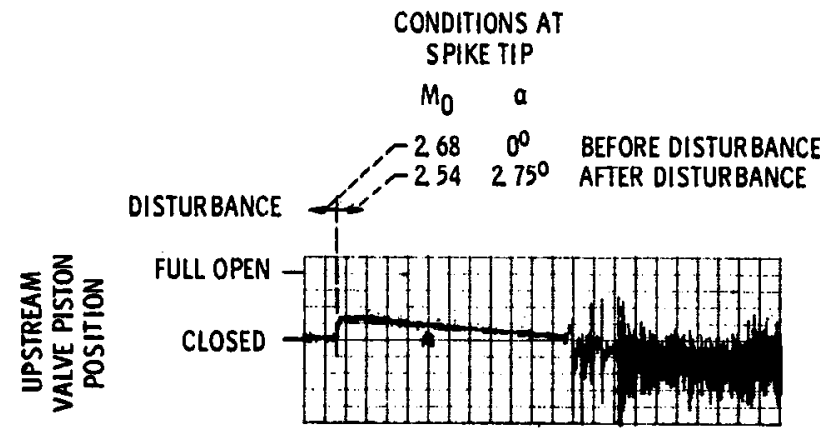

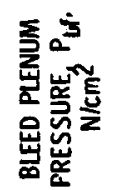

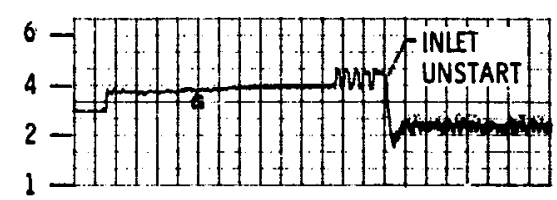

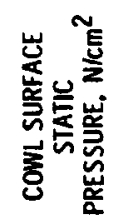

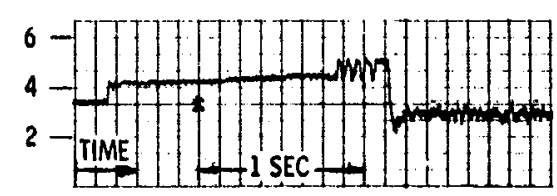
(Valve located at top of inlet looking downstream.) 